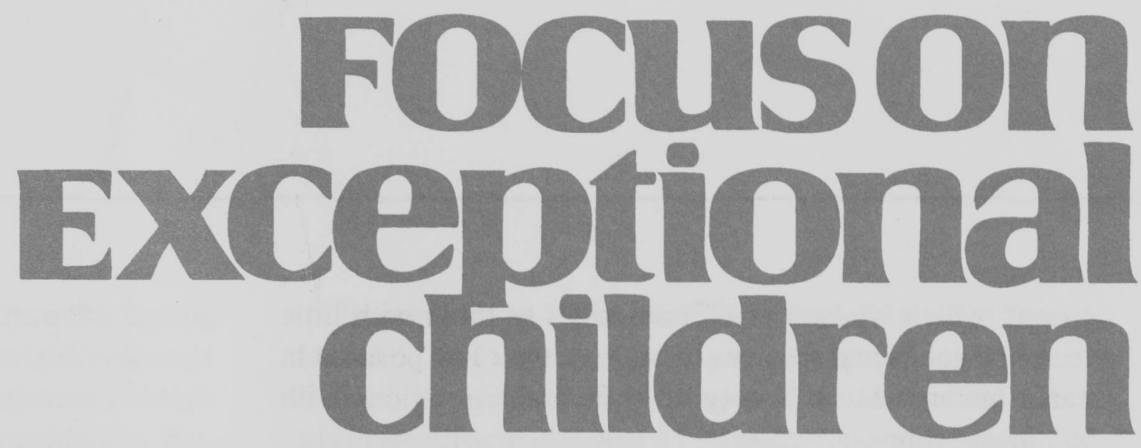

\title{
Poverty, Class, and Disability: A Historical, Social, and Political Perspective
}

\author{
Ellen Brantlinger
}

Although this is a special education publication, in this article I engage the broader topic of creation of social hierarchy. Disability - which is subsumed under the generic construct "losing in stratified relations"- may be somewhat hidden from view. Moreover, for the purpose of clarity of argument, I intentionally oversimplify political positioning by referring to two inclusive sides, "leftists" and "rightists," a framing that challenges the neutrality of most people.

Although this may seem to have little relevance to special educators, insights gained from a "big picture" view can shed light on current practice. I use graduation exit ("gateway") exams to show how social class relations are manifest in school practice. After deconstructing the negative, I put forward ideas for reform and ask readers to join in a movement to transform hierarchical and excluding relations in school and society. Admittedly, these ideas are utopian, but so as not to drift toward unintended places and so that our daily efforts as professionals and citizens allow progress toward prized goals, an ideal community must be imagined (Anderson, 1983).

\section{DOMINATION THROUGH “OTHERING"}

In response to a lack of understanding of domination processes in intergroup relations, Ericka Apfelbaum (1999), a Jewish refuge from Germany to France during World War II, theorizes about the etiology and functioning of power in shaping activities within groups and determining the relations that evolve between them. She argues that mainstream groups create myths based on human features such as race, ability, competency, gender, or class and try to convince others that only they embody important standards. A binary of insiders and outsiders is created. Outsiders are marked, labeled, branded, and stigmatized by identifying names. Naming groups implies a homogeneity of characteristics and outlooks (Shanahan \& Jones, 1999) of those within the collectivity who meet the standard and of Others who supposedly do not.

The dominant group holds maximum power when the distinction between "us" and "them" is believed to be a fundamental, irreversible dissymmetry in which groups have little in common. Centering one group marginalizes Other groups. If the central group considers itself normal and able, Others become abnormal and disabled. Privileging the center is widespread. Education everywhere has built-in limitations in reaching peripheral

Ellen Brantlinger is a professor of special education and Coordinator of the Curriculum Studies Doctoral Program at Indiana University. Her research interests involve inclusive school reform and social class influences on schooling. 
groups, which Nielson (1997) describes as those with little access to goods and services because of their low position in status hierarchies or history of unfavorable relations with dominant groups.

Hierarchies are not purposeless, passive rankings but, rather, are interdependent. Domination depends on subordination. Winners need losers. Superiority needs inferiority. The role, status, and perhaps even raison d'etre of dominant groups depend on the existence of Others.

Basing her analogy of empire-building on Lacan's signification, Bellamy (1998) claims that the identity of the colonizer depends on a "lack" that can be filled only by a colonized Other (p. 342). In special education, for there to be care providers, Others must be identified as having "special needs."

Eagleton (1990) equates domination with oppression. Iris Young (1990) delineates five components of oppression:

1. Exploitation-Structural relation whereby some people exercise their capacities under the control of others

2. Marginalization-Condition of expulsion or exile from labor or social life

\section{Focuson
Exceptional
children}

ISSN 0015-511X

FOCUS ON EXCEPTIONAL CHILDREN (USPS 203-360) is published monthly except June, July, and August as a service to teachers, special educators, curriculum specialists, administrators, and those concerned with the special education of exceptional children. This publication is annotated and indexed by the ERIC Clearinghouse on Handicapped and Gifted children for publication in the monthly Current Index to Journals in Education (CIJE) and the quarterly index, Exceptional Children Education Resources (ECER). The full text of Focus on Exceptional Children is also available in the electronic versions of the Education Index. It is also available in microfilm from Xerox University Microfilms, Ann Arbor, MI. Subscription rates: Individual, $\$ 30$ per year; institutions, \$40 per year. Copyright (C) 2001, Love Publishing Company. All rights reserved. Reproduction in whole or part without written permission is prohibited. Printed in the United States of America. Periodical postage is paid at Denver, Colorado. POSTMASTER: Send address changes to:

$$
\begin{gathered}
\text { Love Publishing Company } \\
\text { Executive and Editorial Office } \\
\text { P.O. Box } 22353 \\
\text { Denver, Colorado } 80222 \\
\text { Telephone (303) 221-7333 }
\end{gathered}
$$

Karen Harris

University of Maryland
Thomas Skrtic University of Kansas

James Shriner University of Illinois

Erica J. Lawrence Editor
Stanley F. Love Publisher
3. Powerlessness-Being subjected to another's control

4. Cultural imperialism-Establishment of the dominant group's experience and culture as the norm, which renders invisible the oppressed groups' perspective

5. Violence-physical attacks, harassment, intimidation, ridicule (pp. 197-198).

Eagleton claims the oppressors' privilege is to define normalcy, decide who is abnormal, and choose how to classify those whom they consider to be abnormal.

Schnog (1997) critiques (dominant) psychological professions for naturalizing oppressive standards of social adjustment. Capshew (1999) notes the tendency of the psychology profession to objectify and dehumanize the mind by using rigid technical classifications. Bruner (1996) sees the dehumanizing effect of technologizing on social science. A result of modern professionalism is the proliferation and burgeoning of "pathologies" (Caplan, 1995; Kutchins \& Kirk, 1997). Special education provides ample evidence of expanding categories of disability and swelling ranks within them.

Composed of credentialed specialists and experts, the middle class bases employment on normative practice. Indeed, credentials define the contemporary social order by giving authority to some (Bourdieu, 1996). Foucault (1980) claims that the "universal intellectual" has been replaced by a "specific intellectual" who has credentials to use technical expertise and work within a discipline. These "faceless professionals" are "competent members of a class going about their business" (p. 7).

Martin (1998) notes Gramsci's observation that even intellectuals from working-class backgrounds cease to serve the interests of their original class and play a conservative role by supporting the status quo. They gain employment by providing services to the elite and keeping society stable by controlling their own and other classes. Control paradigms such as these emerge only in inegalitarian conditions (Rosaldo, 1984)

Foucault (1977) theorizes about how middle-level bureaucrats in schools, penal institutions, and social agencies establish and maintain the norms that control the masses through the major disciplinary instruments of hierarchic surveillance, normalizing sanctions, and examination. Troyna and Vincent (1996) call the expansion and elevation of social service professionals a "reign of experts." They and others (D. E. Brown, 1995; Danforth, 1996; Gordon \& Keiser, 1998) question the value of the proliferating specialized fields or dependence on credentials garnered through higher education-phenomena that have resulted an everexpanding professional middle class (Gouldner, 1979; Wright, 1985). 
In Stigma, Goffman (1963) wrote of how implicit norms and interdependent roles governed relations between staff and patients. Mills (1943) observed how norms and values relate to distributions of power and how professional ideologies create social pathologies. Specializations, as well as classifications, of course, depend on expensive exams to gauge competencies or the lack thereof. As a result of these measures, dominant group members are promoted as superior and subordinates as in need of their wisdom and services. Professionals could find employment in egalitarian societies; however, the greater the "underclass," the greater the proliferation, bureaucratization, and elevation of professional and managerial jobs.

Bracey (1997) criticizes academics who make careers of "collecting grants to fix problems." Unfair sorting phenomena not only have a negative impact on unsuccessful students, democracy is under threat internally when inequalities escalate and divide groups (Osbourne, 1996). The kind of citizen self-respect needed for free participation in democratic deliberation is incompatible with social divisions (Rorty, 1997).

The popular medical model essentializes disability by locating "problems" in individuals and framing traits as fixed (e.g., social determinism in the Bell Curve), which is associated with different goals and behaviors than if attributes are seen as malleable, dynamic, and related to context (Dweck, 1996; Oakes \& Guiton, 1995). Dating at least to Jane Mercer's (1973) theory of the "6-hour-a-day retarded student," many have concurred that "high-incidence disability" (learning disability, mild mental handicap, emotional disturbance, and now attention deficit hyperactivity disorder) has more to do with the nature of school and society than with the individual (Apter, 1996; Smith, 1997).

McDermott and Varenne (1996) call disability a "product of social arrangements" and conclude that labeling invites a public response that multiplies difficulties. It happens officially when school personnel apply disparaging labels as part of their job, and unofficially when high-status students deride poor or otherwise low-status students with epithets such as "grits," "hicks," or "retard."

Derogatory titles/images provide the rationale for spa$\mathrm{cial} /$ psychological distancing. This is a ubiquitous phenomenon in schools and society (Brantlinger, 1993; Harvey, 1996), whether it is producing knowledge that legitimates subordination (Sleeter, 2000); imprisoning Others (BurtonRose, 1998); designating Others as less bright because of a few IQ points (Gould, 1995); enslaving workers in sweatshops (Bales, 1999); keeping minorities out of professions (King, 1995); relegating the disabled to marginal employment (Barton \& Oliver, 1997), living arrangements (Goffman, 1961), social life (Gerschick, 1998; Thomson, 1997); or underfunding urban schools (Orfield, 2000).
In contrast to decontextualized theories of difference, Merton (1994) shows how in a community that emphasizes individualism and competitiveness, students become so hypersensitive to difference that even minor deviance is considered significant. He further observes that such a climate is conducive to bullying, picking on, and putting down.

\section{CONTRIVING LEGITIMACY FOR HIERARCHY: THE ROLE OF IDEOLOGY}

In social hierarchies, those who dominate must work constantly to keep subordinates in their designated places and struggle with potential resistance from them. Ideology is integral to establishing and maintaining power. Ideology, as meaning in the service of power (Thompson, 1990), explains the nature of the social world to actors in relationships. The working of ideology is neither static nor narrow. Inscribed in language (Bakhtin, 1981) and institutional structures (Tyack \& Tobin, 1994); ideology permeates all thought and action (Zizek, 1994). Force can be used to dominate-as it has been historically — but it is more efficient, and nicer, to convince those in low and unequal positions of the legitimacy of status hierarchy and material disparity. In supposed democracies, to exert control, dominant groups must have permission from subordinates.

Consensus is achieved by circulating ideologies that obfuscate bias, rankings, and power imbalances. Ideologies that mystify social rankings take various forms (Thompson, 1990). One is storytelling. Although debunked a generation ago (Keddie, 1973; Ryan, 1972), "cultural deprivation" stories that explain why poor and black children do less well in school and, correspondingly, why intergenerational poverty exists, are still pervasive and persuasive. Deprivationists see immorality and family breakdown, whereas Others see caring behavior set against a breakdown of job opportunity (McDermott \& Varenne, 1996).

Victim-blaming narratives are told not just by naive lay persons but also by those who are prominent in social science fields (see Brantlinger, 1997; Wright, 1993). Another common ideological story is the "American Dream of Social Mobility," which, when combined with "school as a meritocracy" tales, causes achieving and failing students alike to believe the playing field is level so those who excel do so by virtue of natural talents and worthiness and those who fail are lacking these traits. It follows that achievers are entitled to rewards and failing students deserve negative educational and life circumstances.

These ideologies prevent resistance by those at the losing end of relations. When subordinates get wise to the illegitimacy of status or reward differentials, however, new legends must be brought forward to convince them otherwise. Gramsci (1971/1929-1935) introduced the idea of hegemony as a 
dynamic process in which subordinates are continuously offered new persuasive evidence so they will interpret their experiences in ways favorable to the dominant group.

Bourdieu (1996) maintains that, with its material and symbolic power, the dominant group uses schools to sanctify social divisions, a process he calls "symbolic violence." With subordinates as educational consumers, the dominant are positioned as experts who control by setting limits and defining rights through norms made to appear universal through technical and scientific stories about humans. Professionals are the model for, and enforcer of, norms. The pretense of professional knowledge as authorless, disinterested, and value-free is what Nagel (1986) calls the "view from nowhere." Apfelbaum (1999) would locate such knowledge in the powerful center of social life.

\section{DISABLING PRACTICE}

Programs that exclude or relegate students to lesser status than peers are portrayed (by ideological storytelling) as necessary because of substantial, fixed student differences. Entitlement programs (Title 1, special education, Head Start), funded at federal or state levels, presumably give poor children the "cultural preparedness" or "second chance" so they can "reach their potential." Theories about "disadvantage" and "risk" seem charitable, and programs they spawn seem generous. Nevertheless, funding never has been high enough to match the quality education offered affluent students through local tax-based funding (Kozol, 1991; Newman, 1998; Raudenbush, Fotiu, \& Cheong, 1998; Wenglinsky, 1998).

And, regardless of benevolent grounding, compensatory programs inevitably segregate students by ethnicity, race, and class (Artilles \& Trent, 1994; Brantlinger, 1993, 1997; Harry, 1994; Patton, 1998; Robertson, Kushner, Starks, \& Drescher, 1994; Tomlinson, 1999). Poor students are overrepresented in low-status placements, and separation from the mainstream puts them in circumstances even less conducive to learning. A common theory is that limited English proficiency is the source of low achievement. Bartolome (1998) points instead to the exclusion of bilingual students from the benefits of mainstream classrooms. Sorenson (2000) notes that in her poor, Hispanic district, more than 25 percent of students are classified for special education and teachers are unconcerned because they assume that the failure rate is a result of the children being poor.

An assumption underpinning disability classification is that special education service has a positive influence on subsequent school or post-school careers of students; however, efficacy students do not substantiate that claim. To the contrary, consistent with other findings, Reynolds and Wolfe
(1999) report that children who receive special education services have lower reading and math achievement scores than comparable students left in mainstream classes and that students separated for longer times have the lowest scores.

Even if it were possible to equalize children's achievement through separated special education instruction, in terms of long-range outcomes, Jencks (1972) argues that equalizing children's reading scores would not appreciably affect the number of adult economic failures. In spite of what consenting parents may have been told (Brantlinger, 1986), some classification is not intended to benefit those labeled. McGill-Franzen and Allington (1993) describe how, in response to pressures on administrators to have their districts look good on high-stakes tests, some students are classified so their scores are not included in the test pool and the districts' aggregate test results appear better to the public.

In spite of the wealth of evidence about overrepresentation of poor children and children of color in segregated and low-status programs, as well as the early and continuous skepticism about benefits of the programs (Brantlinger, 1997; Dunn, 1968; Mercer, 1973; Oakes \& Guiton, 1995), the practice continues. Barton and Oliver (1997) note that special education's reductionist, within-the-person explanations, when combined with the image of its professionals as caring, patient, and loving, make it difficult to raise questions about low expectations, patronizing and overprotective practices, and stigmatizing labels and services.

Seeming benevolence silences criticism and depoliticizes issues so democratic institutions continue to differentiate those destined to occupy eminent social positions from those over whom they will lord. Subordinates internalize messages about their own inferiority (Brantlinger, 1993) and are persuaded that differentiating and stigmatizing programs are in their own best interests (Brantlinger, 1986), so these forms of symbolic violence take place with their consent, however reluctant and resented. Thus, not only are "the dominant dominated by their domination," as Bourdieu (1998) cites Marx as having said, but because of their submission to unfair practice and their deference to professional authority, those dominated contribute to their own domination.

A popular impression that members of the middle class hold is that poor people do not value education and choose not to do well in school and to live in poverty (Brantlinger, 1993; Brantlinger, Madj-Jabbari \& Guskin, 1996). Because wealthy people are distanced from the poor geographically and psychologically, their impressions are likely to have little connection to the actuality of what living in poverty means. Regardless of myths and stereotypes, poor people share the reverence of the middle class for education, as well as the perception that mobility depends on school achievement and attainment (Brantlinger, 1985; MacLeod, 1987). Yet, in spite of shared perceptions of the good life, what it 
means to achieve, and desire for advancement, low-income students and parents' expectations are low regarding educational and occupational attainment because they are rational in evaluating their circumstances (Ryan, Sheldon, Kasser, \& Deci, 1996).

Furthermore, discriminatory treatment that creates barriers to opportunity has a cumulative effect on the morale of poor people (Mickelson, 1993). The preponderance of past struggles with difficult conditions often means that the poor are alienated from school and resigned to the probability of unfavorable circumstances in the future (Brantlinger, 1985, 1993). Then too, because poor people rarely have benefited from the competitive structure in school, competition does not play the same motivating role in poor communities as it does in middle class suburbs (Brandau \& Collins, 1994).

Some poor people resist domination and engage in various forms of opposition to mainstream authority. Because of effective retaliation by the powerful, however, such resistance usually leads to worsened circumstances for them (MacLeod, 1987; Willis, 1977). But mostly, the achievement of poor children is hampered by inferior school and societal situations (Seiler \& Tobin, 2000). Certainly poor, immigrant, and inner-city families do not choose inadequate schools, however, a review of policy failure in ghetto schooling by Anyon (1997) indicates that these groups have little control over the quality of their schools. Neither do they have the power of the pocketbook to buy houses in neighborhoods known for good schools. The truth is that middle class whites "hog resources" and espouse beliefs about people that cause them to build institutions in ways that perpetuate unfairness (Kozol, 1991; Sleeter, Gutierrez, New, \& Takata, 1992, p. 173). Rorty (1997) complains that suburbanites, who know that social mobility advanced their parents' fates, still see nothing wrong with preventing the mobility of Others and the "belonging to a hereditary caste" or of having a "secession of the successful" (p. 86).

Systems of education and other social agencies (welfare, judicial, penal, mental health) in society intersect with class formation and governmental structures. Legislators pass regulations, and professions develop policy and guidelines for practice. Official sanctions such as these solidify the legitimacy of the symbolic violence of hierarchical relations. The Individuals with Disabilities Education Act (1990) establishes disability categories and due process procedures. Schools must comply with these established procedures, and personnel do so in a way that officially sanctions and monitors power imbalances between local actors in their roles as providers and consumers of services. Hierarchy establishment is depersonalized; school personnel simply follow mandates or adhere to guidelines. Power relations are disguised as they are perpetuated.

\section{THEORIZING SOCIAL CLASS POSITIONALITY}

A myriad of theories have been proposed about social class formation and the causes of poverty. I suggest that these theories can be clustered into two opposing camps: "rightist discourse," which finds deficits in the poor and powerless, and "leftist discourse," which posits culpability in the rich and powerful. My distinction is similar to that of Shor (1999), who claims that "two great rivers of reform flow in opposite directions across the landscapes of American education: The top-down river has been the voice of authority proposing conservative agendas that support inequality and traditional teaching; the bottom-up flow contains multicultural voices for social justice and alternative methods" (vii). My article is mainly a literature review and position paper, but in this section it takes the form of a parable designed to convey a truth or moral lesson.

\section{The Right}

The "self-made man" is a fitting metaphor for the right, and "good things happen to good people" a fitting motto. Rightists assume that interpersonal competition is essential to humans, that it is not only inevitable but also appropriate. They believe that hard-working, bright, and capable people naturally seek advancement - and rightfully get aheadand, conversely, that those at the losing/lower end of social hierarchies get what they deserve and are where they belong.

Rightists come in two forms: first, the social determinists, who take survival of the fittest at face value and eschew any kind of social mediation; and, second, the benevolent leaders who believe their role is to be charitable in guiding and governing the Other. Rightist maneuvering by social determinists have emanated from the central positioning and control of church, royalty, industrialists, and colonial powers. This rightist, hierarchical thinking leads to wars, genocide, exclusion, and various other forms of oppression.

Readers may be puzzled about why I put these two types of rightists in the same box. Indeed, compassionate leaders would be quick to condemn the blatant self-centeredness of social determinists, arguing like Bersoff (1999) and David (1999) that unethical behavior probably is not the result of a moral judgment hiatus but, rather, a corruption driven by a desire for personal gain. Yet, the compassionate leaders do assume hierarchical positions over Others, and because they occupy the unmarked centers of stratified institutions, their neutrality must be questioned (Apfelbaum, 1999; Eichstedt, 1998).

Both types of rightists affirm the validity and righteousness of social class distinctions. Both are "masters of the universe," with the former forging ahead to realize ambitions regardless of any damaging impact on Others and the latter diligently — and patronizingly — controlling the impulses of 
Others for their own good, of course, and for the sake of society.

It is easy to understand why wealthy corporate elites gain from and support hierarchical social arrangements, but motives for the complicity of liberal middle class people are less clear. Indeed, conservatives have used liberalism as a disparaging epithet for "compassionate leaders" who support using tax money for social programs. Because sustenance of the liberal educated class is precisely the social spending they endorse supposedly for Others (Brantlinger \& Madj-Jabbari, 1998), I categorize these liberals as self-serving and, therefore, rightist.

Although the social determinist right exalts in wielding power, Epstein and Steinberg (1997) assert that the liberal point of view ignores issues of power and liberals do not name their own advantage. E. O. Wright (1985) postulates that the middle class is a contradictory class that does not benefit from corporate profits to the same extent as the elite classes, but their financial and social interests still are tied to elites. They gain from the market economy.

Bourdieu (1998) uses "neo-liberalism" to refer to the dominant discourse of political submission to economic rationality, the undivided reign of the market and consumer, and the withering away of the state. Wells (2000) equates neo-liberalism with "new market ideology" and the free market reform rationale for school choice policy (e.g., charter schools, public vouchers for private schools), which she sees as a backlash against redistributive reform aimed at decreasing disparities in education and society.

Moreover, Wells observes that in the present political and economic climate, people who question neo-liberalism are promptly dismissed. Bourdieu claims that people collectively, in the mode of consensus, have an "atavistic faith in the historical inevitability of productive forces" and "utter a fatalistic discourse which transforms economic tendencies into destiny," yet warns that the "flagrant inadequacies of the market are undermining the public interest and liquidating the gains of the welfare state." He condemns the French public for judging the "political candidates according to narrow-minded, regressive, security-minded, protectionist, conservative, xenophobia" (p. 18). So, because the compassionate leaders benefit from liberal social spending as well as the market economy, I position them on the right.

\section{The Left}

"Do unto others" is the leftist motto (see Sober \& Wilson, 1998). An apt metaphor is "all for one and one for all," with its emphasis on social reciprocity. Like their rightist counterparts, the left has two sides: the skeptical rationalist, who deconstructs rightist discourse and espouses "conspiracy theories" about the unacceptable goals and tactics of winners in social hierarchies, and the idealistic moralist, who imagines egalitarian communities and acts so as to accomplish them.

In terms of the rational, suspicious side of leftism, Ball (1994) reminds that, according to Foucault, the real political task of the left is to criticize the institutions that appear neutral and independent, and to do so, to unmask the "political violence which has always exercised itself obscurely through them" (p. 27). Said (1994) points out that the challenge of intellectual life is in dissent against the status quo (p. xv).

Some postmodernists eschew the rational and the notion of progress. Harvey (1996) recalls the Frankfurt School's challenge of this type of hegemonic instrumental rationality but notes that it sought an alternative rationality that had the power to give a deeper sense of meaning to life through a rough consensus of solidarity around moral values. So, too, Bourdieu (1996) insists that reason and rational knowledge are the best weapons against domination. Although he conceives of social justice as a heterogeneous set of concepts, Harvey endorses a "decentralized communitarianism which espouses egalitarianism, nonhierarchical forms of organization, and widespread local empowerment and participation in decision-making as the political norm" (p. 181). He favors anything that mitigates the destructive, degrading, and debilitating practices of racism [and, I would add "that reduces disablism" to his mission].

For Rorty and Dewey, as for me, the left has a democratic agenda. Rorty (1997) claims that Dewey set the tone for the American left by offering a new account of what America was, in the hope of mobilizing Americans as political agents. His principal target was "institutionalized selfishness" (p. 25). Dewey "used 'truly democratic' as a supreme honorific" (Rorty, p. 17). He envisioned schools and society as a "Great Community" (Greene, 1993) and democracy as a town meeting (Rorty, p. 25).

In characterizing political poles, Rorty maintains: "The right never thinks that anything needs to be changed and sees the Left's struggle for social justice as mere troublemaking and utopian foolishness." The Left, by Rorty's definition, is the "party of hope." The Left in the academy, however, has become "spectatorial and retrospective" and "permitted cultural politics to supplant real politics" (p. 14).

Harvey (1996) believes that academics err in being individualistic, professionally fragmented, and involved in egotistically driven enterprises. In terms of a constructive role, Rorty observes that "top-down leftist initiatives come from people who have enough security, money, and power themselves, but nevertheless worry about the fate of people who have less," such as "muckraking exposés by journalists, novelists, and scholars" (p. 53).

Rorty claims that leftists all "meant pretty much the same thing by justice - decent wages and working conditions, and 
the end of racial prejudice" (p. 59). (Again, class and disability should be on Rorty's list.) Regarding education, leftists scrutinize tightly-framed, discipline-based knowledge and conclude that, because much of it is unrelated to people's lives, its value is mainly as class-distinguishing cultural capital (Bourdieu, 1977, 1984; Freire, 1989; Shor, 1999).

Clearly, this analysis sets up a moral binary of leftist as good and rightist as bad. In doing this, I am in good company. Rorty (1997) writes: "Understanding evil was basic to the Progressive Movement in American politics" (p. 34). In naming evil, it is important to step back and depersonalize this claim by pointing out that a binary refers to two ends of a continuum in which there are few pure cases. Most people vacillate between various confounded, intertwined, and overlapping strands of leftist and rightist thinking and acting. So, when asked, "Who is on the right? Who benefits from rightist discourse?" the glib answer is that rightists generally are elites or social conservatives.

According to my definition, however, rightist discourse is espoused by more middle class people than might be expected and is subscribed to by working classes or impoverished classes who incorrectly identify their positions in hierarchies. According to Bourdieu (1996), social hierarchy dis-simulates itself to those it dignifies no less than to those it excludes. Freedom from oppression is founded on awakening consciousness (Freire, 1973).

One reason for the recent accelerated sway toward narrow rightist thinking is that leftist ideals were contaminated by the failure of communism and socialism. The leaders of these national experiments, however, rather than being real communal activists, inherited the hierarchical tactics of rightist despots-the tsars, military dictators, and royalists - the only models of leadership they had. Few among our ancestors have not been guilty of oppression, whether a result of their own initiation of social cruelty or complicity with those in power. Nevertheless, rightist rule also always has been countered by leftist activists and social movements (Crocco, Munro \& Weiler, 1999; Freire, 1985; Horton, 1998; Walker, 1997).

It will be no surprise to readers that I position myself squarely on the left-although I do not pretend to be good enough to always act according to communal or empathic ideals. My critical perspective, however, has evolved so that I am quick to notice hierarchical thinking and bias in various forms of rightist discourse. Social inequalities are, by definition, relational (Whitty, 2000), so advocating for Others destabilizes the power and status of the mainstream and threatens other academics. Leftists who go against the conservative grain are vulnerable to censure and rejection (Wilson, 1995).

According to Whitty (2000), who writes from a British perspective, it is risky to confront middle class privilege in the present rightist climate. Fine (1992) claims that although politics "saturates all research, those of us who 'come clean' [identify as being on the left] run the risk of being portrayed as distinctly biased" (p. 230). Yet, as Zizek (1994) maintains, everything is ideological and political, so it is best to locate ourselves within this complex reality and be open about our politics and ethics and comply with Becker's (1963) request that scholars answer the fundamental question: "Whose side are you on?"

Besides choosing sides, those of us who are on the left theoretically must work toward change in our professional lives and be willing to give up material advantage and social status so egalitarian ideals actually can be realized. We are not exempt from our own critical insights (Bourdieu, 1998).

\section{A SHORT HISTORY OF SOCIAL STRUGGLE}

Those who are invited to write for Focus on Exceptional Children are assigned a topic and title. The words "history" and "politics" were included in my title. I am neither a trained historian nor a political scientist, but as with all scholars, I tell about disability, social class, and equality and justice from my own perspective and in my own terms. It is not just scholars who theorize. All humans ruminate about their psychological, social, and physical surroundings. Formal subject area disciplines likely evolved from casual contemplations about the world, and informal conjecture may be as astute and practical as official, disciplined theories. I maintain that the history of people with disabilities is parallel to all groups declared outside a community of equals, whether for reasons of race, gender, ethnicity, language usage, social class, sexual orientation, or any difference perceived according to the normative standard currently in vogue. Othering results in stigmatizing classifications, bodily violence (infanticide, "mercy" killing, forced sterilization), or banishment and segregation.

In his book, Human Universals, Donald Brown (1991) reports his meta-analysis of anthropological findings and concludes that there are 118 human universals. The bad news is that the "universal people," to various degrees, create social hierarchies that correspond to differential power and status relations. Not surprisingly, these distinctions are based on gender, ethnicity, and traits such as perceived beauty and capability, or on "family" (ethnic, racial) ties. The good news is that the universal people also inevitably develop a moral code based on empathy and social reciprocity. Thus, Brown finds a universal tension between hierarchical (rightist) and communal (leftist) thinking worldwide.

In thinking about history, "drift" seems to capture the idea of things happening without conscious and rational deliberation. People tend to believe that there has been a gradual progression of countries toward independence and a 
"modern" improvement in material and social conditions. Yet, Ahmad (1992) argues that supposed recent decolonization has mainly involved bringing to leadership a national bourgeoisie. These new leaders typically are people who had not been in the dangerous forefront of their country's anticolonial struggles (p. 18). So, although power changes hands, the class structure of decolonizing nations does not change, nor does the class character of imperialist nations diminish.

Ahmad claims that this modern time period has witnessed an unprecedented globalized growth of the technological power of capitalism, which he calls the "global triumph of colonialism" and "an imperialized world" (p. 17). The United States is the largest imperial power in historya fact that is neither mentioned nor faced (Kailin, 2000). Americans have a difficult time acknowledging inequalities (O'Brien, 1998) and do not refer to themselves as capitalists. When capitalism is mentioned, as with other neo-liberal discourse, it is framed in Enlightenment terms as freedom and progress and not as imperialism (Sleeter, 2000).

As with all colonization, there is a great impact on local cultures and civic relations within and between national borders. There is an increasing concentration of extreme wealth in a relatively few international families and increasing poverty and hopelessness among large sectors of society worldwide (Anyon, 2000). Anyon refers to the material losses of the working class as a "pauperization of wages." She reports that currently one half of all workers are just above the poverty line and 24 percent are under the poverty line. Only one in 10 Americans makes more than $\$ 65,000$ annually. One fifth of all workers now are part-time, which means that they have no fringe benefits or job security.

Garmarnikow and Green (2000) report poverty at 33 percent, with increasing class polarization in England. These economic conditions pit citizens against each other. And the struggle is less often between classes than within them. Elites compete with each other for the rewards of high-paying and high-status positions. Internal strife among impoverished people is unlikely to have personal benefits for anyone. Again, it is based on false consciousness of class interest and the wrong identification of the "enemy." For example, white working class men hold blacks accountable for their own economic insecurity and conditions of job fragility (Weis \& Fine, 1996). In cases of such misperceptions, both parties are likely to be losers.

While the subordinates struggle among themselves, Sleeter notes that "elites increasingly call the shots about education" and "legislate social controls that bind students to the existing social order." Similarly, Neill (2000) contends that the globalization of business has resulted in corporate intervention for a certain kind of schooling that reproduces the current social class and wage structure.
Regarding social class in England, Whitty (2000) observes that the middle class has effectively colonized public education for itself.

Saavreda (2000) describes the effects of "the power of opulence on education" as a "commodification of knowledge," a claim that reflects Bourdieu's (1984) theory of how the educated class manufactures its distinction through cultural capital. Carlson and Apple (1998) refer to Gramsci's observation that advanced capitalist societies were in an era called "fordism" (factory mass production) with the emergence of a mass consumerism that not only drives industrialization but also social life through the ways by which public institutions are organized (pp. 6-7). Referring to the extensive use of cars and tremendous growth of suburbs, Kunstler (2000) tallies up the huge economic, social, and spiritual costs that America pays for its consumer-crazed lifestyle.

The burgeoning corporate development results in a market mentality in educational decision-making in which technological knowledge is valued. With the technocratic dominance, teachers are trained to accept depersonalized methods and be "reduced to a passive, objective, and efficient distributor of technical information" (Leistyna, 1999, p. 7) The prevailing notion is that teachers should learn an aggregate of technical skills (Hatton, 1997). With its emphasis on subject-area methods and disability-category-bound survey courses, teacher education is a conservative determinant of special and general education teacher practice (Brantlinger, 1996).

Not only does the technical expedience mentality of curriculum and pedagogy have an impact on what is learned or not learned, but Carlson and Apple (1998) also warn of the negative effects of this kind of schooling on students' identity formation.

I would add that students who do well in school and those who do not alike pay a devastating social price for ratcheting up the excessive social competition and credentialing purposes of schooling and the commodification of knowledge.

As economic conditions are in flux-improving dramatically for some and worsening drastically for others-democratic principles and ethical social relations are in jeopardy. Moral vacillation among humans is the history that has become apparent to Lynn Hunt (2000). Hunt surmises that only periodically do peoples come up with "truths" about moral codes that they hold to be "universal" and "self-evident." She points out that this type of thinking occurs during revolutionary periods such as the French Revolution, which spawned a moral code known as the Enlightenment, or in the writing of the Constitution after the United States' break with England. In both cases, there was a groundswell of populist thinking about basic human rights and the nature of civil relations. 
If idealistic thinking happens only erratically when people have hope or there is some form of societal upheaval, people must drift away from ideals most of the time. Perhaps they get so caught up in the banal routines of daily life that they do not see the big picture and do not think past the mundane.

Regarding a recent leadership dispute of a national sociology organization, Feagin (1999) concludes that the controversy was fueled by the recognition that mainstream research has moved away from urgent moral and practical concerns voiced by critical sociologists. Feagin claims that the issues are the same ones facing the whole nation: Will we continue to allow traditional elites [rightists] in large institutions to control important discourse and decisions, or will we take our democratic traditions seriously?

Reflecting on Hunt's theory, the rapidly paced technological development and economic and political globalization of current times seems to constitute a revolutionary period in which the social class polarization of wealth and power have caused many to react by becoming both idealistic and activist. The protests against the World Trade Organization in Seattle in 2000 and the World Bank in Switzerland are representative of a growing contingent of leftist Americans who are organizing and are willing to participate in public action. Although critical theorists refer to "the state" as under the control of dominant groups, Gramsci argues that governments can be political entities and moral agents with transformative potential (Martin, 1998, p. 73).

Politicians who endorse leftist agendas can be elected. Various philosophies about the role of government in relation to social institutions, citizens, and business enterprise wax and wane. In a period of deregulation of the market, rampaging consumerism, globalization and colonization by industry, rapid ecological decline, and rightist control of public institutions, many seek leaders with a sense of urgency about the disastrous dividing and impoverishing effects of global capitalism. "It transpires that there is not a region in the world where manifestations of anger and discontent with the capitalist system cannot be found" (Harvey, 1996, p. 430).

Rather than drifting along passively (Eliasoph, 1998), it is time to take stock of current trends and make deliberate democratic decisions about the future (Elster, 1998). Oettingen (1996) suggests that people generate positive fantasies and mental images depicting future events and scenarios; that optimism has beneficial effects on motivation, cognition, and affect. Schudson (1998) advocates the need to capture the national imagination with a large moral mission. Although I conclude this article with recommendations for school reform, I first provide a recent specific history of the politics of the right in high-stakes testing.

\section{GATEWAY TESTS: A CASE OF CLASS CONFLICT ON THE RAMPAGE}

After laying out generic social and political trends, it seems useful to show how rightist discourse manifests itself in the current adoption by states of high-stakes graduation ("gateway") tests. Formerly, students who stuck it out for 12 years and completed the required courses-many of which were adapted to their achievement levels-graduated from high school. Now a growing number of states have instituted gateway tests to gauge secondary students' eligibility for a diploma (Langenfeld, Thurlow, \& Scott, 1997).

A common rationale given for adopting high-stakes testing is that high school diplomas did not guarantee that students met a certain standard of literacy skills or had a general knowledge level. Therefore, as a credential, the diploma had little credibility. Higher education personnel and businesses were unable to judge students' level of competence based on the diploma. Things have changed. If statistics elsewhere are similar to local ones, between a third and a half of sophomores fail the test initially. Of those remaining in school their senior year, 14 percent fail the exam (Lane, 2000). State legislation mandates that potential graduates who do not pass the exams do not receive a diploma.

Given the high rates of failure on high-stakes tests, a public, or at least student and parent, outcry might be expected. But, in my community, besides a few editorials written in a calm and tentative tone and one letter of complaint when it was discovered that the new "non-graduates" would be unable to attend the local technical and vocational college, little opposition has surfaced. An exception is an upcoming class-action lawsuit brought by the American Civil Liberties Union based on the argument that gateway tests violate special education students' constitutional rights (Associated Press, 2000, April 30).

The lack of public outrage about the dire consequences of tests might seem puzzling, but in the short time since the measures were mandated, it already has become clear which students readily pass the tests on the first try and which students fail on each try (Fairtest, 1999-2000a). Students who pass are mostly white and from middle-class families. Educated in high "ability" groups in elementary school, then in honors, gifted/talented, or advanced placement sections during their secondary years, passing students have high gradepoint averages and score above average on other tests. In contrast, students who fail are largely poor and/or of color. In major urban districts across Indiana, minority failure rates are higher than 50 percent (Associated Press, 2000, April 30) - rates similar to those of blacks and Latinos in Texas (Fairtest, 1999-2000a).

Racially disproportionate outcomes are expected. Black students generally test below White students (Jencks \& 
Phillips, 1999). A Texas judge acknowledged that graduation tests had a "legally meaningful and disparate impact against African American and Latino students" (Fairtest, 19992000a, p. 1) but concluded that "test-based discrimination is not illegal because only a high stakes exam can force students and educators to work hard enough and be focused enough to learn the "basic skills' measured" by the test (p. 11).

Not only do students who fail gateway tests score below average on all tests, but they also have low grade-point averages, high rates of grade-level retention, more punished infractions, and poor school attendance records. Some are identified as disabled, "were disabled" in the past but currently are not classified, or barely miss the cutoff criterion for disability classifications. If they are not in special education, failing students are likely to have been singled out for other compensatory and remedial interventions. Those who fail are "at risk" already. Previously, "risk" referred to subsequent poor school performance and potential for dropping out of school - or being pushed out of school (Fine, 1991). Indeed, high school dropouts can be identified as early as third grade. Now, risk encompasses the probability of not passing gateway tests.

Given the high correlations between all forms of school inferiority and failure (e.g., the stability of ranked orderings), a viable explanation for the lack of open opposition to the gateway exams is that they represent just one more instance of failure for certain students. The negative impact of these tests is on students who already are at the losing end of all school and societal hierarchies, students who are the most powerless. Not only are students who do not pass gateway exams on the low end of school evaluative and status continua, but they also are disproportionately poor, of color, and/or have limited English proficiency. Their low status in school mirrors their family's status in the community. They "happen" to live in an impoverished, ghetto (Conley, 1999; Oliver \& Shapiro, 1995). They attend schools and classes with the fewest resources (Anyon, 1997; Kozol, 1991) and the least academic push (Chazan, 2000).

Orfield (2000) reports strong data about segregation by race and ethnicity in urban school districts, as well as mass chaos and disorganization with a high rate of administrator turnover so that "consistency is terribly low in anything they do." Noddings (2000) complains that many children get "subtractive schooling." Not only do the outcomes add up to below zero, but the time spent in school also is agonizing for them (Brantlinger, 1993). This has been the case for generations. Kliebard (1986) cites a factory inspector in Chicago, who in 1913 questioned children of immigrants about whether they would choose to continue working long hours in sweatshops or go to school. Of 500 children, 412 preferred factory labor to the monotony, humiliation, and sheer cruelty they experienced in school.

\section{The Discourse of Decline}

A stated rationale for mandating gateway tests is that the very real possibility of failure provides the incentive for teachers to improve their instruction and for students to work harder (Fairtest, 1999-2000a). Politicians and the media continuously portray teachers (and students) as lazy, incompetent, and lacking motivation to excel (Mortimore \& Mortimore, 1999). This concern seems to be grounded in discourses of societal decline and some people not pulling their weight and therefore becoming a burden on others.

Gateway tests are billed as a "tough love" way to deal with corrupted modern adolescents, neglectful parents, and inept teachers. The tests are to provide a reality message that will force certain students to come to school, behave themselves, and "try." The "get tough" approach also undergirds the symbolic violence of low grades, stigmatizing placements, and castigating disciplinary measures (Fairtest, 1999-2000a). These measures seem to be for failing students' own sakes. "For your own good" often is a stated reason for violence in child-rearing (Miller, 1986).

So, in spite of high-stakes testing being punitive, states advertise themselves as caring. Because they sometimes fund compensatory programs to help failing students gain the skills and knowledge required to pass the test, they claim generosity. Governing bodies tout the necessity of disciplining or closing doors to students as well as their own righteousness when they institute undesirable "opportunities."

The first special education class I taught was an "Opportunity Room"- - a misnomer that fooled nobody, especially my students. Subdivided from a larger classroom, ours was the only room to have a letter affixed to its number. We often heard angry general education teachers threaten, "If you don't shape up, you'll end up in 209A!" that "A" became as significant and humiliating as the scarlet letter.

Part of the national discourse about decline is linked to a fear that the United States is behind in global competitiveness because of inadequate workers. A compelling case has been made against the validity of this argument. Bracey (2000) detects flaws in statistics that purport to document American students' comparative weaknesses. According to Berliner and Biddle (1995), the agitation about academic decline and the United States losing ground compared to other nations is a "manufactured crisis." Claims about inferior workers distract the public from concerns they might have about worldwide colonization of land and people by Western transglobal corporations (Martin \& Schumann, 1997; Sleeter, 2000). Rothstein (1999) concludes that, in spite of reports to the contrary, student achievement in the United States has improved consistently. Nevertheless, achievement has not prevented jobs with sustainable salaries from disappearing for Americans (Wilson, 1996). 
Even if achievement were declining, tougher standards for student performance most likely will not be effective in improving either the schools or the economy (Kohn, 1998; Meier, 2000; Ohanian, 1999; Starratt, 1994). Smyth and Shacklock (1998) reject contentions that schools can or should be engines for economic restoration. Regarding apprehension about the scarcity of competent graduates in technical fields-see Nation at Risk (U. S. Department of Education, 1983) and America 2000 (U.S. Department of Education, 1991)—evidence of high unemployment rates among those with advanced degrees, and especially in mathematics and science, contradicts such claims (Boutwell, 1997; O’Brien 1998; Noddings, 1994).

Public hysteria about academic and social decline may be generated to fill the emotional (and media) gap left when the sensationalism of the cold war threat of communism disappeared. A form of cold war logic is behind the current fear that America needs better educated workers if it is to compete in global markets and on battlefronts. This perspective is not unique to Americans. Hyperbolic concern about declines in functional literacy tied to fears of workforce collapse and national vulnerability is taking place in England (Ball, Kenny, \& Gardiner, 1990) and Australia (Taylor, Rizvi, Lingard \& Henry, 1997). If inferior workers really were the cause of economic decline, why would companies move to countries whose citizens have even lower literacy levels?

While complaining about incompetent United States employees, corporate CEOs insist that they must relocate where there are no minimum wages or expensive environmental regulations to stay afloat. They imply that they are doing it for the sake of the country's economy. Meanwhile, transnational corporations make huge profits, have infinite unregulated power, and are colonizing citizens of rich and poor nations alike (Sleeter, 2000). Ahmad (1992) claims that economic realities surround and saturate us (p. 70), so that corporate repressions and the rise of a compliant and affluent bourgeoisie (college-educated, professional and managerial classes) are interrelated (p. 36).

Responsive to those in power, all media serve a master (McChesney, 1999; McLeod \& Hertog, 1999). American media maintain the position and power of corporate businesses and bureaucratic institutions by circulating dominant-value messages (Viswanath \& Demers, 1999). Communication networks, viewed around the world, are controlled by less than two dozen enormous profit-making corporations (McChesney, 1997). These mass media recommend and support business-oriented measures to correct supposed problems and negatively portray teachers, students, and anyone who protests the system (Glasser \& Bowers, 1999). Britzman (1992) calls the highly publicized idea of declining teacher quality an "arranged, slippery history that hides its interestedness and politics of selection" (p. 73).

Globalization discourses frame education policies the world over (Taylor, Rizvi, Lingard, \& Henry, 1995). Kailin (2000) argues that high-stakes testing, retention, and accountability standards are new ways to create notions of failure and hold back the masses. She questions how these reforms can be constructive, when, for example, in the city of New Orleans, 91 of 103 schools are considered below adequate ("failing") schools so the official response is to subject students, teachers, and administrators to stringent repercussions. School personnel feel so pressured by punitive accountability measures that they are driven to cheat (Associated Press, 2000, June 8). Neill (2000) calls high-stakes tests "a bad reflection of even the better parts of standards." He delineates that the high-stakes testing movement causes: (1) a narrowing of curriculum through elimination of curricular depth because tests cover broad factual knowledge; (2) increased student dropout or pushout rates; (3) a weakening of constructive purposes of tests; (4) speeded-up or intensified mechanistic school (busy) work; (5) bureaucratized, centralized school power; (6) disempowered teachers; (7) alienated students; and (8) standardized minds.

Regardless of how they are rationalized, gateway tests are punitive from the perspective of students who fail or fear they will fail. Given the poor track record that punitive or segregated approaches have had in improving circumstances for "at-risk" students, draconian measures such as denying the high school diploma on the basis of test scores, after students have spent 12 years in school (Chaffee, 1998), seems unlikely to have a constructive effect on students, schools, communities, or the nation.

Teachers and administrators predict that gateway tests will have an adverse impact (Neill, 1997). These tests may be a "final straw" that becomes a catalyst for students who are likely to fail the test to leave school even earlier than they would have otherwise. If school attendance and attainment are as beneficial as believed, early school culmination cannot be perceived as being in the public's or the students' own best interest. Meier (1994) insists that if we want students to stay in school, schools cannot be designed for shame. Regardless of social class affiliation, students are ashamed of failure (Brantlinger, 1993).

\section{The Essential Question: Who Benefits?}

In contrast to the deleterious test outcomes for lowincome students, students from middle-class, educated families tend to pass gateway exams on the first try. Middle- and upper-class students almost always end up on the winning end of ranked orderings. Given that test scores inevitably sort students along social class lines and, based on what is 
known about correlations between measures, the classlinked outcomes could have been anticipated. If gateway tests do not benefit the students they disqualify from high school graduation, it is important to ask Gramsci's (1971/1929-1935) essential question: "Who benefits" from instituting such exams?

Explanations for the success of middle-class students' are numerous, including that they "come from genetically superior stock," "acquire cultural capital from educated families," "internalize parental values and caring about school," "are raised to consider educational achievement and attainment the epitome of success and perhaps even their reason for existence," "receive respectful home treatment that nurtures the high self-esteem necessary for competence," "have emotionally supportive parenting that allows them to concentrate on learning," and "are not distracted by the tensions of substance abuse or antisocial or criminal lifestyles" (see Brantlinger, Madj-Jabbari, \& Guskin, 1996). This lay and professional reasoning attributes middle-class success to superior student and family characteristics-again, to personal traits rather than structural distinctions or differential institutional response to each class.

In addition to the perceptions of people from the middle class about the strengths of their class, other, less stereotypic explanations can be proposed for affluent students' patterns of school success. One theory is rational behavior: School efforts of middle class students depend on the conviction that $\mathrm{K}-12$ achievement enables access to higher education, which permits access to professional jobs with salaries high enough to maintain lifestyles to which they are accustomed. Students who engage in maintaining status not only are aware that achievement at each level is necessary for subsequent schooling but also that family finances are available to allow them to attain middle class goals. This assurance provides the incentive that motivates students to work in school. Aspirations enhance achievement only when combined with expectations of sufficient resources for advanced education. Given the conducive conditions of monetary support and parental know-how, middle-class students are on a collegebound track from the time they are born.

Another neutral explanation for the class-related school success rates is that middle-class people of European American heritage control the culture of social institutions so it mirrors their home culture (Bourdieu, 1977). In their professional roles, college-educated parents determine the curricular and pedagogical factors that privilege children of their class (Apple, 1993). Henry (1995) writes of a Eurocentric curriculum and of the importance of anti-colonial struggle even in institutions that are within the borders of colonial powers.

Some might challenge the "neutrality" of these social-class reproduction theories. They are consistent with Marxist or critical theories of domination and oppression in that they highlight how social interactions and societal institutions are stratified along social class lines. Nevertheless, I dub them neutral because, although they name class advantage, they fail to pinpoint human intentionality in seeking advantaged and exclusive conditions and of winning at Others' expense. Instead they rely on theories about culture as a stock of commonsense beliefs about what is right, natural, normal (Rochon, 1998) and about tacit knowledge as visceral and internal (Vygotsky, 1978). Because they theorize the body/subject as socially inscribed and managed (Shapiro, 1999), those who benefit appear to be mere puppets controlled by external forces. Agency and deliberate intentions remain invisible. Yet, if there are no intentions, there is no responsibility and no possibility for change.

Another reason that I call these theories neutral is that the scholars who espouse highly theoretical class correspondence theories offer few obvious connections to local school contexts and few suggestions about how to make schools more equitable. Some convey resignation to stratified relations or they are not deeply introspective about their own status or their role in producing hierarchies (see Brantlinger, 1999). They rarely declare or perhaps even notice which side they are on (Becker, 1963). Others focus on students and offer continuously newer technical remedies for failure. Sleeter (2000) argues that "researchers from dominant groups have a long history of producing knowledge about oppressed groups that legitimates their subordination" ( $p$. 10). Few researchers have thought it important to turn the scholarly gaze upward to understand why students win or why additional measures are developed to allow more opportunities for some to win.

Although nothing is neutral, I use "political" for theories that address the intentionality and self-serving value orientations of actors and that connect to an agenda for transformative social change. Within these parameters, one can ask pertinent political questions about reasons for the widespread adoption of gateway exams, such as: If existing evaluative measures already ranked students the same way as gateway exams, why were additional tests needed? If who fails and who passes gateway tests is the same as for all school measures, and hence predictable, what is the purpose of the exams? Who needs them? Who wants them? Why are they so popular among legislators and voters? On what social meanings do these tests depend? Real answers to these questions are complex, interactive, and definitively and openly political because they focus on intentional acts.

A credible response to who benefits is that gateway tests are a good source of revenue for test producers. Through connections to the media, they announce declining achievement rates for American students and link these rates to downward national economic trajectories-current, fore- 
seen, or imagined. They scare the public into adopting yet another expensive accountability measure, if not to gauge students' achievement, then the competence of teachers or preservice teachers. So exams are the result of a conspiracy by corporations such as ETS, to keep money flowing their way, especially to the CEOs of these supposedly not-forprofit companies.

Test producers deliberately circulate knowledge about a crisis in education, then market remedies for improving literacy and knowledge. According to McNeil (1995, 2000), the winners are vendors who produce official curricula and design and market tests. And they are the bureaucrats who gain politically from being messengers of the perennially popular doom-and-salvation rhetoric.

A related reason for the onslaught of tests is that corporations have to pinpoint a cause for low wages and salary discrepancies. Constructing "low-scorers" as personal losers, corporations have a convenient scapegoat for social problems. Low test scores mean that the poor are inferior and undeserving. By getting public concurrence that inferior workers and welfare for the unemployed and underemployed burden others, corporations detract attention from their own questionable practices and how government protections for them ("business welfare") are a drain on public funds. It is hard not to be skeptical of the flawed logic of executives who blame unprepared employees for economic decline, then move their companies to countries with the lowest levels of educational attainment and, opportunely, the lowest wages. Unions are busted while CEOs do the necessary downsizing" that creates unemployment and underemployment and decimates fringe benefits. Then, for their "good work," they "upsize" their own salaries as well as profits for corporate shareholders.

No wonder those who have power over economic conditions like to believe in the inferiority of American workers and the neutrality of market trends! "Inevitable" systemic conditions allow them to deny their intentionality and avoid being held accountable for contributing to dire outcomes for the working class. The stronger the measures used to prove inferiority and the more replications of the extensiveness of Others' faults, the more credible are the arguments about personal blame for low social status and income disparities among families. It is no coincidence that those found to be inadequate are the least powerful citizens. During a time of economic boom and rising wages for affluent Americans, these stratifying practices clearly strengthen the image of others' flaws and justify the uneven wage structure. Differential scores explain haves and have-nots not only to those advantaged by testing practices but also to those disadvantaged by them. That is how hegemony works.

The question of who benefits raises the suspicion that a closer-to-home explanation for gateway tests-in terms of middle-class people who believe they have no corporate connections - is that they also give students from powerful families opportunities to show superiority. They, too, need evidence of widely diverging exam results to provide a grounding for privilege. Based on positive personal attribute accounts of school and post-school success, it follows that educated people have earned social and material advantage in school and post-school situations. One answer to the above questions, then, is that those who win in the games of education and occupation seek increasingly conclusive evidence of superiority, which, in turn, justifies their taking home larger and larger shares of the national economic pie. When all students earn a diploma, its value is undermined. To have worth, status markers must be scarce. An educated class, that benefits from the diploma's scarcity, has the power to limit it to people of its class by legislating gateway exams and other such measures.

Why do dominant classes depend on ideologies that revolve around reasons for Others' failures? Cutthroat competition and slanted playing fields are not admired or condoned. Selfishness and greed are subject to approbation by religious and secular standards. Those who are in control, and who win-the educated middle class-have to legitimize their actions. According to Baumeister (1996), "the desire to think well of oneself is one of the most fundamental and pervasive motivations in human psychological function" (p. 27). Draconian measures adopted to keep Others down while documenting their inferiority can be understood as attempts to restore or improve the self-evaluation of the perpetual winners.

\section{OPPOSITION TO DOMINANCE CREATING INCLUSIVE SCHOOLING: A ROLE FOR THE LEFT}

As promised, I follow my deconstruction of rightist discourse and practice with ideas for democratic school practice that are consistent with leftist goals for communal and reciprocal social relations. In considering what might work in modern times, some general principles can be drawn from intellectuals such as Polanyi (1957), who claims that reciprocity-giving and receiving according to need-has been the dominant mode of exchange in traditional societies and should be the principle for social relations in complex industrial economies. Rawls (1971) recommends distributive justice in which the neediest in society (e.g., the self-defined rather than school-defined disabled) are the first to get scarce resources.

Particularly regarding benefits to students who have been classified as having "special needs," I agree with Paul, Rosselli, and Evans (1995) about the necessity of integrating school restructuring and special education reform. I also 
concur with Weinstein, Madison, and Kuklinski (1995) that general and special educators should collaborate to challenge deficit thinking about children. I believe that I should follow the advice of Oliver Sacks (1995), who studies the inner worlds and identities of his disabled "neighbors," in emphasizing that they are no less human for being different. Kittay (1999), mother of a child with severe disabilities, examines the dependency work of women and writes that her aim is to "find a knife sharp enough to cut through the fiction of our independence" (p. xiii). Similarly, Koggel (1998) suggests that, instead of limiting thinking to what individuals need as independent, autonomous agents, a relationship approach to equality asks what moral persons embedded in relationships of interdependency need so they can flourish.

Meier (1994) pressures educators to look at the purpose and nature of schools so their means and ends align better. She insists that high-stakes measures are not the answer (Meier, 2000). It is imperative that educators not create debilitating roles for children by implementing differentiating educational policies and practices (Oakes, Quartz, Ryan \& Lipton, 2000), by providing subtractive education to the children of powerless families (Noddings, 2000), or by consenting to draconian measures advocated by a corporate elite whose main concern is personal profit and not children's interests (McNeil, 2000).

Middle-class parents must be convinced of the societal benefits of valuing Other people's children and not demanding personal advantage for their own (Brantlinger, MadjJabbari, \& Guskin, 1996). Administrators must "respect the moral bottom line" and not give in to illegitimate requests by self-centered school patrons (Kohn, 1998, p. 576). In terms of purging stratifying systems, Mehan, Hubbard, and Villannueva (1994) claim that untracking works when students are accommodated without being assimilated and when they develop a critical perspective and are determined not to be held back by racism.

During his 9-year teaching career in a Los Angeles refugee neighborhood Pruyn (1999) took a Freirean approach to helping students become aware of and change their societal positions. The vision of school reform proposed by the unnamed editors of Rethinking Schools (2000) resonates with my beliefs. They set forth principles to guide reform initiatives; among them:

- Schools are responsible to communities, not the marketplace.

- Schools must be actively multicultural and antiracist.

- Schools must promote social justice for all.

- Schools must be geared toward learning for life and the needs of a democracy.

- All must receive adequate resources; must collaborate with parents and other community members. They insist that communities as well as schools must be revitalized.

Because of the routinized forms of noninvolvement of teachers in real decision-making and the general disruption of (punitive) top-down school high-stakes reform pressures, Herr (2000) advocates creating change from within schools by asking teachers to name their own concerns. Saavedra (2000) recommends that teachers have more control and respect so they will get over their fears and quit privileging the expert, external knowledge often aligned with corporate interests and demands. She appeals to them to quit allowing themselves to be pathologized and forced into unhealthy competitiveness with each other so they become disempowered technicians; that is, they should fight the oppressive control forced on them in the name of somebody else's idea of reform.

Saavedra sees a need for solidarity and authentic partnerships among teachers, and suggests that they join with teachers' movements. An example of teacher activism is the case of six Florida teachers who traveled 6 hours to return their bonuses (for students' high test scores) to Governor Jeb Bush, to focus attention on what they see as misuse of the Florida Comprehensive Achievement test to rank schools (Fairtest, Winter 1999-2000b, p. 5).

But a leftist movement for equity and social justice on the part of teachers must be joined by others. If social activism is to be successful, it must be revitalized and broadened to have the critical mass necessary for an effective social movement (Marwell \& Oliver, 1993; Tarrow, 1998). Such activism will require work and commitment, as well as the bravery not only to leave the mainstream but also to confront it. Social movements are necessarily extrainstitutional; for durable change, they must disrupt rather than interrupt dominant practice (Katzenstein, 1998).

In terms of defining roles for intellectuals - recall that I assign a thinking and theorizing role broadly to all humans, yet believe that those of us paid to set educational trends in academia or lead in public schools should be held most accountable for deep, critical thinking about how to improve life circumstances for all. Gramsci (1971/1929-1935) defines intellectuals as consciously reflective social analysts [who interrogate their own tacit knowledge and class-embedded ideologies]. For Gramsci, the test of intellectual production by the organic intellectual of the working class was the extent to which it fused with the life of the masses and mobilized them to think critically about their circumstances (Martin, 1998, p. 58), which is similar to Freire's (1973) consciousness-raising approach to literacy instruction.

Said (1994) claims that real intellectuals are never more themselves than when they are moved by metaphysical passions about disinterested principles of justice and truththat is, when they denounce corruption, defend the weak, 
and defy imperfect or oppressive authority (p. 6). C. Wright Mills (1963) sees a need for intellectuals who have impassioned social visions. Scatamburlo (1998) calls for ruthless criticism of everything existing - that is, criticism that is not afraid of its own conclusions or of conflict with existing power relations. Bourdieu (1996) maintains that reason and rational knowledge remain our best weapon against domination.

Although Harvey (1996) argues that it is dangerous in academia these days to confess to being meta about anything (p. 2), the grand meta-narratives about social equity (e.g., Marx) and Enlightenment ideals of equality and justice are relevant to today's society. Walkerdine (2000) sees the need for creating new spaces in which people can reinvent themselves (and Others) in more positive ways. In discussing gender relations, Walkerdine notes that subject positions have been invented for people so she recommends, for example, that as women's roles change, men must be prepared to cope with the loss of a certain kind of masculinity. In a similar vein, if society is to change, new roles and identities clearly must be developed for the traditional oppressors as well as the traditionally oppressed.

\section{REFERENCES}

Ahmad, A. (1992). In theory: Classes, nations, literatures. London: Verso. Anderson, B. (1983). Imagined communities. London: Verso.

Anyon, J. (1997). Ghetto schooling: A political economy of urban educational reform. New York: Teachers College Press.

Anyon, J. (2000, April 25). Political economy of an affluent suburban school district: Only some students get the best. Paper presented at American Educational Research Association annual meeting, New Orleans.

Apfelbaum, E. (1999). Relations of domination and movements for liberation: An analysis of power between groups. Feminism \& Psychology, 9(3), 267-272.

Apple, M. W. (1993). Official knowledge. New York: Routledge.

Apter, T. (1996). Expert witness: Who controls the psychologist's narrative? In R. Josselson (Ed.), Ethics and process in the narrative study of lives (pp. 22-44). Thousand Oaks, CA: Sage.

Arons, S. (1997). Short route to chaos: Conscience, community, and reconstitution of American schooling. Amherst: University of Massachusetts Press.

Artilles, A. J., \& Trent, S. (1994). Overrepresentation of minority students in special education: A continuing debate. Journal of Special Education, 27, 410-437.

Associated Press (2000, April 30). Summit to address failure rates among black students. Bloomington Herald Times, C3.

Associated Press (2000, June 8). Cheating teachers increasingly common: Emphasis on top test scores fuels adult deception, critics say. Bloomington Herald Times, A4.

A vision of school reform. (2000). Rethinking Schools, 14(4), 27.

Bakhtin, M. (1981). The dialogic imagination (C. Emerson \& M. Holquist, Trans.). Austin: University of Texas Press. (Original work published 1975)

Bales, K. (1999). Disposable people: New slavery in the global economy. Berkeley: University of California Press.
Ball, S. (1994). Education reform - a critical and post-structuralist approach. Milton Keynes: Open University Press.

Ball, S., Kenny, A., \& Gardiner, D. (1990). Literacy, politics, and the teaching of English. In I. Goodson \& P. Medway (Eds.), Bringing English to order (pp. 47-86). London: Falmer.

Bartholomé L. I. (1998). The misteaching of academic discourses: The politics of language in the classroom. Boulder, CO: Westview.

Barton, L., \& Oliver, M. (1997). Special needs: Personal trouble or public issue? In B. Cosin \& M. Hales (Eds.), Families, education and social differences (pp. 89-101). London \& New York: Routledge with The Open University.

Baumeister, R. F. (1996). Self-regulation and ego threat: Motivated cognition, self-deception, and destructive goal setting. In P. M. Gollwitzer \& J. A. Bargh (Eds.), The psychology of action: Linking, cognition and motivation to behavior (pp. 27-47). New York: Guilford Press.

Becker, H. (1963). Outsiders: Studies in the sociology of deviance. New York: Free Press.

Bellamy, E. J. (1998). "Intimate enemies": Psychoanalysis, Marxism, and postcolonial affect. In R. Miklitsch (Special Issues Editor), PsychoMarxism: Marxism and psychoanalysis late in the twentieth century (pp. 341-359). South Atlantic Quarterly, 97(2).

Berliner, D. C., \& Biddle, B. J. (1995). The manufactured crisis: Myths, fraud, and the attack on America's public schools. Reading, MA: AddisonWesley.

Bersoff, D. M. (1999). Explaining unethical behavior among people motivated to act prosocially. Journal of Moral Education, 28(4), 413-428.

Bourdieu, P. (1977). Outline of a theory of practice, Cambridge, UK: Cambridge University Press.

Bourdieu, P. (1984). Distinction: A social critique of the judgment of taste. Cambridge, MA: Harvard University Press.

Bourdieu, P. (1996). The state nobility: Elite schools in the field of power (L. C. Clough, trans.). Stanford, CA: Stanford University Press.

Bourdieu, P. (1998). Acts of resistance against the tyranny of the market. New York: Press.

Boutwell, C. E. (1997). Shell game: Corporate America's agenda for schools. Bloomington, IN: Phi Delta Kappa.

Bracey, G. W. (1997). The truth about America's schools: The Bracey reports, 1991-1997. Bloomington, IN: Phi Delta Kappa.

Bracey, G. W. (2000). The TIMSS “final year" study and report: A critique. Educational Researcher, 29(4), 4-10.

Brandau, D. M., \& Collins, J. (1994). Texts, social relations, and workbased skepticism about schooling: An ethnographic analysis. Anthropology \& Education Quarterly, 25, 118-136.

Brantlinger, E. A. (1985). What low-income parents want from schools: A different view of aspirations. Interchange, 16, 14-28.

Brantlinger, E. A. (1986). Making decisions about special education: Do low-income parents have the information they need? Journal of Learning Disabilities, 20, 95-101.

Brantlinger, E. A. (1993). The politics of social class in secondary schools: Views of affluent and impoverished youth. New York: Teachers College Press.

Brantlinger, E. A. (1996). The influence of preservice teachers' beliefs about pupil achievement on attitudes toward inclusion. Teacher Education \& Special Education, 19(1), 17-33.

Brantlinger, E. A. (1997). Using ideology: Cases of non-recognition of the politics of research and practice in special education. Review of Educational Research, 67, 425-460.

Brantlinger, E. A. (1999). Inward gaze and activism as moral next steps in inquiry. Anthropology \& Education Quarterly, 30(4), 413-429.

Brantlinger, E. A. (1999). Class moves in the movies: What Good Will Hunting teaches about social life. Journal of Curriculum Theorizing, 15(1), 105-120. 
Brantlinger, E. A., \& Madj-Jabbari, M. (1998). The conflicted pedagogical and curricular perspectives of middle-class mothers. Journal of Curriculum Studies, 30(4), 431-460

Brantlinger, E., Madj-Jabbari, M., \& Guskin, S. L. (1996). Self-interest and liberal educational discourse: How ideology works for middle-class mothers. American Educational Research Journal, 33(3), 571-598.

Britzman, D. P. (1992). Teachers under suspicion: Is it true that teachers aren't as good as they used to be? In J. L. Kincheloe \& S. R. Steinberg (Eds.), Thirteen questions: Reframing education's conversation (pp. 73-80). New York: Lang.

Brown, D. E. (1991). Human universals. Philadelphia: Temple University Press.

Brown, D. K. (1995). Degrees of control: A sociology of educational expansion and occupational credentialism. New York: Teachers College Press.

Bruner, J. S. (1996). The culture of education. Cambridge, MA: Harvard University Press.

Burton-Rose, (1998). The celling of America: An inside look at the United States prison industry. Common Courage Press.

Caplan, P. J. (1995). They say you're crazy. Reading, MA: Addison-Wesley.

Capshew, J. H. (1999). Psychologists on the march: Science, practice, and professional identity in America, 1929-1969. Cambridge, MA: Cambridge University Press.

Carlson, D., \& Apple M. W. (1998). Introduction. In D. Carlson \& M. W. Apple (Eds.). (1998). Power/knowledgelpedagogy: The meaning of democratic education in unsettling times (pp. 1-38). Boulder, CO: Westview.

Chazan, D. (2000). Beyond formulas: Mathematics and teaching: Dynamics of the high school algebra class. New York: Teachers College Press.

Conley, D. (1999). Being black, living in the red: Race, wealth, and social policy in America. Berkeley: University of California Press.

Crocco, M. S., Munro, P., \& Weller, K. (1999). Pedagogies of resistance: Women educator activists, 1880-1960. New York: Teachers College Press.

Danforth, S. (1996). Autobiography as critical pedagogy: Locating myself in class-based oppression. Teaching Education, 9(1), 3-4.

David M. (1999). Explaining unethical behavior among people motivated to act prosocially. Journal of Moral Education, 28(4), 413-428.

Dunn, L. M. (1968). Special education for the mildly retarded: Is much of it justifiable? Exceptional Children, 355(22).

Dweck, C. S. (1996). Implicit theories as organizers of goals and behavior. In P. M. Gollwitzer \& J. A. Bargh (Eds.), The psychology of action: Linking, cognition and motivation to behavior (pp. 69-90). New York: Guilford Press.

Eagleton, T. (1990). The ideology of the aesthetic. Oxford: Basil Blackwell.

Eichstedt, J. L. (1998). Reproducing racial and class inequality: Multiculturalism in the arts. In J. O'Brien \& J. A. Howard (Eds.), Everyday inequalities: Critical inquiries (pp. 237-252). Malden, MA: Blackwell.

Eliasoph, N. (1998). Avoiding politics: How Americans produce apathy in everyday life. Cambridge NY: Cambridge University Press.

Elster, J. (1998). Introduction. In J. Elster (Ed.), Deliberative democracy (pp. 1-18) Cambridge, NY: Cambridge University Press.

Epstein, D., \& Steinberg, D. L. (1997). Love's labours: Playing it straight on the Oprah Winfrey show. In D. L. Steinberg, D. Epstein, Debbie Johnson, \& R. Johnson (Eds.), Border patrols: Policing the boundaries of heterosexuality (pp. 32-65). London: Cassell.

Fairtest (1999-2000a, Winter). Court rules for high-stakes Texas test. Examiner, 14(1), 1, 11.

Fairtest (1999-2000b, Winter). Florida teachers refuse bonuses for high test scores, Examiner, 14(1), 5.

Feagin, J. R. (1999, Oct. 15). Soul-searching in sociology: Is the discipline in crisis? Chronicle of Higher Education, B4-B6.

Fine, M. (1991). Framing dropouts: Notes on the politics of an urban public high school. Albany: State University of New York Press.
Fine, M. (1992). Disruptive voices. Ann Arbor: University of Michigan Press.

Foucault, M. (1977). Discipline and punish: The birth of the prison. Harmondsworth, NY: Penguin.

Foucault M. (1980). Power/knowledge: Selected interviews and other writings 1972-1977 (Colin Gordon, Ed.). New York: Pantheon.

Freire, P. (1973). Education for critical consciousness. New York: Seabury.

Freire, P. (1985). The politics of education: Culture, power, and liberation. South Hadley, MA: Bergin \& Garvey.

Freire, P. (1989). Pedagogy of the oppressed. New York: Continuum.

Garmarnikow, E., \& Green, T. (2000, April 25). Social capital, social class, citizenship and educational policy under new labor. Paper presented at American Educational Research Association annual meeting, New Orleans.

Gerschick, T. J. (1998). Sisyphus in a wheelchair; men with physical disabilities confront gender domination. In J. O'Brien \& J. A. Howard (Eds.), Everyday inequalities: Critical inquiries (pp. 189-211). Malden, MA: Blackwell.

Glasser, T. L., \& Bowers, P. J. (1999). Justifying change and control: An application of discourse ethics to the role of mass media. In D. Demers \& K. Viswanath (Eds.), Mass media, social control, and social change: A macrosocial perspective (pp. 399-418). Ames: Iowa State University Press.

Goffman, E. (1961). Asylums. New York: Penguin,

Goffman, E. G. (1963). Stigma: Notes on the Management of Spoiled Identity. Englewood Cliffs, NJ: Prentice Hall.

Gordon, M., \& Keiser, S. (Eds.). (1998). Accommodations in higher education under the Americans with Disabilities Act. New York: Guilford.

Gould, S. J. (1995). Curveball. In. S. Fraser (Ed.), The bell curve wars: Race, intelligence, and the future of America (pp. 11-22). New York, NY: Basic Books.

Gouldner, A. W. (1979). The future of intellectuals and the rise of the new class. New York: Seabury Press.

Gramsci, A. (1971/1929-1935). Selections from the prison notebooks (Q. Hoare \& G. N. Smith, Eds.). New York: International Publishers.

Greene, M. (1993). The passions of pluralism: Multiculturalism and the expanding community. Educational Researcher, 22(1), 13-18.

Harry, B. (1994). The disproportionate representation of minority students in special education: Theories and recommendations. Alexandria, VA: National Association of State Directors of Special Education.

Harvey, D. (1996). Justice, nature and the geography of difference. Cambridge, MA: Blackwell.

Hatton, E. (1997). Teacher educators and the production of bricoleurs: An ethnographic study. Qualitative Studies in Education, 10(2), 237-257.

Henry, A. (1995). Growing up black, female, and working class: A teacher's narrative. Anthropology \& Education Quarterly, 26(3), 279-305.

Herr, K. (2000, April 26). Creating change from within: One school's dance with district mandates and school-wide inquiry. Paper presented at American Educational Research Association Annual Meeting, New Orleans.

Horton, M. (1998). The long haul: An autobiography. New York: Teachers College Press.

Hunt, L. (2000, Feb. 8). Tracing the origins of human rights. Patten lecture, Indiana University, Bloomington.

Jencks, C. (1972). Inequality: A reassessment of the effect of family and schooling in America. New York: Harper \& Row.

Jencks, C., \& Phillips, M. (Eds.). (1999). The black-white test score gap.

Kailin, J. (2000, April 27). The hidden dimensions of liberal racism: An anti-racist response. Paper presented at American Educational Research Association annual meeting, New Orleans.

Katzenstein, M. F. (1998). Stepsisters; feminist movement activism in different institutional spaces. The social movement society: Contentious 
politics for a new century (pp. 195-216). Lanham, MD: Rowman \& Littlefield.

Keddie, N. (1973). The myth of cultural deprivation. London: Penguin.

King, B. (1995). Locking ourselves in: national standards for the teaching profession. Teaching, \& Teacher Education, 10(1), 95-108.

Kittay, E. F. (1999). Love's labor: Essays on women, equality, and dependency. New York and London: Routledge.

Kliebard, H. (1986). The struggle for the American curriculum: 1893-1958. Boston: Routledge and Kegan Paul.

Koggel, C. M. (1998). Perspectives on equality: Constructing a relational theory. Lanham, MD: Rowman \& Littlefield.

Kohn, A. (1998). Only for my kid: How privileged parents undermine school reform. Phi Delta Kappan, 569-577.

Kozol, J. (1991). Savage inequalities: Children in America's schools. New York: HarperPerennial.

Kunstler, J. H. (2000, May 20). Can America survive suburbia? Talk at Bloomington Convention Center sponsored by Bloomington Restorations. Bloomington, IN.

Kutchins, H., \& Kirk, S. A. (1997). Making us crazy: DSM: The psychiatric bible and the creation of mental disorders. New York: Free Press.

Lane, L. (2000, April 7). ISTEP Results. Bloomington Herald Tribune, p. A1, 9

Langenfeld, K., Thurlow, M., \& Scott, D. (1997). High stakes testing for students: Unanswered questions and implications for students with disabilities. NCEO Synthesis Report 26.

Leistyna, P. (1999). Presence of mind: Education and the politics of deception. Boulder, CO: Westview Press.

MacLeod, J. (1987). Ain't no making it: Leveled aspirations in low-income neighborhoods. Boulder, CO: Westview Press.

Martin, H. P., \& Schumann, H. (1997). The global trap. New York: Zed Books Ltd.

Martin, J. (1998). Gramsci's political analysis: A critical introduction. New York: St. Martin.

Marwell, G., \& Oliver, P. (1993). The critical mass in collective action: A micro-social theory. Cambridge, NY: Cambridge University Press.

McChesney, R. W. (1997). Corporate media and the threat to democracy. New York: Seven Stories Press.

McChesney, R. W. (1999). Rich media, poor democracy. Champaign, IL: University of Illinois.

McDermott, R. P., \& Varenne, H. (1996). Culture, development, disability. In R. Jessor, A. Colby, \& R. A. Shweder (Eds.), Ethnography and human development: Context and meaning in social inquiry (pp. 101-126). Chicago \& London: University of Chicago.

McGill-Franzen, A., \& Allington, R. L. (1993). Flunk 'em or get them classified. Educational Research, 22(1), 19-22.

McLeod, D. M., \& Hertog, J. K. (1999). Social control, social change and the mass media's role in the regulation of protest groups. In D. Demers \& K. Viswanath (Eds.), Mass media, social control, and social change: A macrosocial perspective (pp. 305-330). Ames: Iowa State University Press.

McNeil, L. (1995). Local reform initiatives a national curriculum: Where are the children? In L. McNeil (Ed.), The hidden consequences of a national curriculum (pp. 13-46). Washington, DC: American Educational Research Association.

McNeil, L. (2000). The educational costs of standardization. Rethinking Schools, 14(4), 8-13.

Mehan, H., Hubbard, L., \& Villannueva, I. (1994). Forming academic identities: Accommodation without assimilation among involuntary minorities. Anthropology \& Education Quarterly, 25(2), 91-117.

Meier, D. (1994, Winter). A talk to teachers. Dissent, pp. 80-87.

Meier, D. (2000, June 12). Interview: Do tests hurt poor kids? Newsweek, p. 79.
Mercer, J. R. (1973). Labeling the mentally retarded. Berkeley: University of California Press.

Merton, D. (1994). The cultural context of aggression: The transition to junior high school. Anthropology \& Education Quarterly, 25(1), 29-43.

Meyer, D. S., \& Tarrow, S. (1998). The social movement society: Contentious politics for a new century. Lanham, MD: Rowman \& Littlefield.

Mickelson, R. A. (1993). Minorities and education in plural societies. Anthropology \& Education Quarterly, 24(3), 269-276.

Miller, A. (1986). For your own good: Hidden cruelty in child-rearing and the roots of violence. New York: Noonday Press.

Mills, C. W. (1943). The professional ideology of social pathologists American Journal of Sociology, 49(2), 165-180.

Mills, C. W. (1963). Power, politics, and people: The collected essays of C. Wright Mills (I. L. Horowitz, Ed.). New York: Ballantine.

Mortimore, P., \& Mortimore, J. (1999). The political and the professional in education: An unnecessary conflict? In J. S. Gaffney \& B. J. Askew (Eds.), Stirring the waters: The influence of Marie Clay (pp. 221-238). Portsmouth, NH: Heinemann.

Nagel, T. (1986). The view from nowhere. New York: Oxford University Press.

Neill, M. (1997). Testing our children: A report card on state assessment systems. Cambridge, MA: Fairtest.

Neill, M. (2000, April 28). The nature and consequences of high-stakes testing in a time of global reaction. Paper presented at American Educational Research Association annual meeting, New Orleans.

Newman, K. (1998). Falling from grace: The experience of downward mobility in the American middle class. New York: Vintage.

Nielsen, H. D. (1997). Preface. In H. D. Nielsen \& W. K. Cummings (Eds.), Quality education for all: Community-oriented approaches (pp. ix-x). New York \& London: Garland.

Noddings, N. (1994). Foreword. In C. M. Brody \& J. Wallace (Eds.), Ethical and social issues in professional education (pp. ix-x). Albany: State University of New York Press.

Noddings, N. (2000, April 27). Address to Division B annual meeting. American Educational Research Association annual meeting, New Orleans.

Oakes, J., \& Guiton, G. (1995). Matchmaking: The dynamics of high school tracking decisions. American Educational Research Journal, 32, 3-33.

Oakes, J., Quartz, K. H., Ryan, S., \& Lipton, M. (2000). Becoming good American schools: The struggle for civil virtue in school reform. San Francisco: Jossey-Bass.

O'Brien, J. (1998). Introduction. In J. O'Brien \& J. A. Howard (Eds.), Everyday inequalities: Critical inquiries (pp. 1-39). Malden, MA: Blackwell.

Oettingen, G. (1996). Positive fantasy and motivation. In P. M. Gollwitzer \& J. A. Bargh (Eds.), The psychology of action: Linking, cognition and motivation to behavior (pp. 236-259). New York: Guilford Press.

Ohanian, S. (1999). One size fits few: the folly of educational standards. Westport, CT: Heineman.

Oliver, M. L., \& Shapiro, T. M. (1995). Black wealth/white wealth. New York: Routledge.

Orfield, G. (2000, April 27). What have we learned from school reconstitution? Paper presented at American Educational Research Association annual meeting, New Orleans.

Osbourne, A. B. (1996). Practice into theory into practice: Culturally relevant pedagogy for students we have marginalized and mornalized. Anthropology \& Education Quarterly, 27(3), 285-314.

Patton, J. M. (1998). The disproportionate representation of African Americans in special education: Looking behind the curtain for understanding and solutions. Journal of Special Education, 32(1), 25-31. 
Paul, J. L., Rosselli, H., \& Evans, D. (Eds.). 1995). Integrating school restructuring and special education reform. Fort Worth, TX: Harcourt Brace.

Polanyi, K. (1957). The great transformation. Boston: Beacon.

Pruyn, M. (1999). Discourse wars in Gotham-West: A Latino immigrant urban tale of resistance and agency. Boulder, CO: Westview Press.

Raudenbush, S. W., Fotiu, R. P., \& Cheong, Y. F. (1998). Education Evaluation and Policy Analysis, 20(4), 253-267.

Rawls, J. (1971). A theory of justice. Cambridge, MA: Harvard University Press.

Ray, C. A., \& Mickelson, R. A. (1990). Corporate leaders, resistant youth, and school reform in Sunbelt City: The political economy of education. Social Problems, 37, 178-190.

Reynolds, A. J., \& Wolfe, B. (1999). Special education and school achievement: An exploratory analysis with a central-city sample. Educational Evaluation \& Policy Analysis, 21(3), 249-269.

Robertson, P., Kushner, M. L., Starks, J., \& Drescher, C. (1994). An update of participation rates of culturally and linguistically diverse students in special education: The need for a research and policy agenda. Bilingual Special Education Perspective, 14(1), 1-9.

Rochon, T. R. (1998). Culture moves: Ideas, activism, and changing values. Princeton, NJ: Princeton University Press.

Rorty, R. (1997). Achieving our country: Leftist thought in twentiethcentury America. Cambridge, MA: Harvard University Press.

Rosaldo, M. (1984). Toward an anthropology of self and feeling. In R. A. Shweder \& R. A. LeVine (Eds.), Culture theory: Essays in mind, self, and emotion. Cambridge, MA: Cambridge University Press.

Rothstein, R. (1999). The way we were? The myths and realities of America's student achievement. Century Foundation.

Ryan, R. M., Sheldon, K. M., Kasser, T., \& Deci, E. L. (1996). All goals are not created equal: An organismic perspective on the nature of goals and their regulation. In P. M. Gollwitzer \& J. A. Bargh (Eds.), The psychology of action: Linking cognition and motivation to behavior (pp. 7-26). New York: Guilford Press.

Ryan, W. (1972). Blaming the victim. New York: Random House.

Saavedra, E. (2000, April 27). Teacher study groups as contexts for transformative learning, and practice. Paper presented at American Educational Research Association annual meeting, New Orleans.

Sacks, O. (1995). An anthropologist on Mars: Seven paradoxical tales. Great Britain: Picador.

Said, E. (1994). Representations of the intellectual: The 1993 Reith lectures. London: Vintage.

Scatamburlo, V. L. (1998). Soldiers of misfortune: The new right's culture war and the politics of political correctness. New York: Peter Lang.

Schnog, N. (1997). On inventing the psychological. In J. Pfister \& N. Schnog (Eds.), Inventing the psychological: Toward a cultural history of emotional life in America (pp. 3-16). New Haven, CT: Yale University Press.

Schudson, M. (1998). The good citizen: A history of American civic life. Cambridge, MA: Harvard University Press.

Seiler, G., \& Tobin, K. (2000, April 26). Students' perceptions of repression, social justice, and failure to learn science in an inner city high school. Paper presented at annual meeting of American Educational Research Association, New Orleans.

Shanahan, J., \& Jones, V. (1999). Cultivation and social control. In D. Demers \& K. Viswanath (Eds.), Mass media, social control, and social change: A macrosocial perspective (pp. 31-50). Ames: Iowa State University Press.

Shapiro, S. B. (1999). Pedagogy and the politics of the body: A critical praxis. New York: Garland.

Shor, I. (1999) Preface. In I. Shor \& C. Pari (Eds.), Education is politics: Critical teaching across differences, $K-12$ (pp. vii-ix). Portsmouth, $\mathrm{NH}$ : Boynton/Cook (Heinemann).
Sleeter, C. E. (2000, April 28). Keeping, the lid on: Multicultural curriculum and the organization of consciousness. American Educational Research Association Annual Meeting, New Orleans.

Sleeter, C., Gutierrez, W., New, C. A., \& Takata, S. R. (1992). Race and education: In what ways does race affect the educational process? In J. L. Kincheloe \& S. R. Steinberg (Eds.), Thirteen questions: Reframing education's conversation (pp. 173-182). New York: Lang.

Smith, T. J. (1997, March). Storying moral dimensions of disordering: Teacher inquiry into the social construction of severe emotional disturbance. Paper presented at American Educational Research Association annual meeting, Chicago.

Smyth, J., \& Schacklock, G. (1998). Re-making teaching: Ideology, policy and practice. London \& New York: Routledge.

Sober, E., \& Wilson, D. S. (1998). Unto others: The evolution and psychology of unselfish behavior. Cambridge, MA: Harvard University Press.

Sorenson, K. (2000, April 26). Why do we have so many failing students? Leaping into schoolwide inquiry and school reform. Paper presented at American Educational Research Association annual meeting, New Orleans.

Starratt, R. J. (1994). Building an ethical school: A practical response to the moral crisis in schools. London: Falmer.

Tarrow, S. (1998). Power in movement; Social movements and contentious politics ( $2 \mathrm{~d}$ ed.). Cambridge, MA: Cambridge University Press.

Taylor, S., Rizvi, F., Lingard, B., \& Henry, M. (1997). Educational policy and the politics of change. London and New York: Routledge.

Thompson, J. B. (1984). Studies in the theory of ideology. Berkeley: University of California Press.

Thompson, J. B. (1990). Ideology and modern culture: Critical social theory in the era of mass communication. Stanford, CA: Stanford University Press.

Thomson, R. G. (1997). Extraordinary bodies: Figuring physical disability in American culture and literature. New York: Columbia University Press.

Tomlinson, S. (1999, June 15). Race and special education. Paper presented at International Research Colloquium on Inclusive Education, University of Rochester, New York.

Troyna, B., \& Vincent, C. (1996). The ideology of expertism: The framing of special education and racial equality policies in the local state. In C. Christensen \& F. Rizvi (Eds.), Disability and the dilemmas of education and justice (pp. 131-144). Philadelphia: Open University Press.

Tyack, D., \& Tobin, W. (1994). The "grammar" of schooling: Why has it been so hard to change? American Educational Research Journal, 31, 453-479.

U.S. Department of Education (1983). A Nation at Risk. Washington, DC: Department of Education.

U.S. Department of Education. (1991). America 2000. Washington, DC: Department of Education.

Viswanath, K., \& Demers, D. (1999). Mass media from a macrosocial perspective. In D. Demers \& K. Viswanath (Eds.), Mass media, social control, and social change: A macrosocial perspective (pp. 3-30). Ames: Iowa State University Press.

Vygotsky, L. S. (1978). Mind in society. Cambridge, MA. Harvard University Press.

Walker, A. (1997). Anything we love can be saved: A writer's activism. New York: Random House.

Walkerdine, V. (2000, April 26). Feminist and critical perspectives on education and psychology. Paper presented at American Educational Research Association annual meeting, New Orleans.

Weinstein, R. S., Madison, S. M., \& Kuklinski, M. R. (1995). Raising expectations in schooling: Obstacles and opportunities for change. American Educational Research Journal, 32, 121-159. 
Weis, L., \& Fine, M. (1996). Narrating the 1980s and 1990s: Voices of poor and working-class white and African American men. Anthropology \& Education Quarterly, 27(4), 493-516.

Wells, A. S. (2000, April 26). When local control meets the free market: School choice policy for the new millennium. Paper presented at American Educational Research Association annual meeting, New Orleans.

Wenglinsky, H. (1998). Finance equalization and within-school equity: The relationship between education spending and the social distribution of achievement. Educational Evaluation \& Policy Analysis, 20(4), 269-283.

Whitty, G. (2000, April 25). Schooling and the reproduction of the English middle classes. Paper presented at American Educational Research Association annual meeting. New Orleans.

Willis, P. (1977). Learning to labor: How working class kids get working class jobs. New York: Columbia University Press.
Wilson, J. K. (1995). The myth of political correctness: The conservative attack on higher education. Durham, NC: Duke University Press.

Wilson, W. J. (1996). When work disappears: The new world of the urban poor. New York: Knopf.

Wright, E. O. (Ed.). (1985). Classes. London/New York: Verso.

Wright, S. E. (1993). Blaming the victim, blaming society, or blaming the discipline: Fixing responsibility for poverty and homelessness. Sociology Quarterly, 34(1), 1-6.

Young, I. M. (1990). Justice and the politics of difference. Princeton, NJ: Princeton University Press.

Zizek, S. (1994). Introduction: The spectre of ideology. In S. Zizek (Ed.), Mapping ideology (pp. 1-33). London/New York: Verso.

\section{New Ways of Looking at}

\section{Learning Disabilities}

\section{Connections to Classroom Practice}

Lou Denti, California State University, Monterey Bay

Patricia Tefft-Cousin, Late of Indiana University at Purdue

This text bridges the gap between general and special education pedagogy by including constructivism, humanist, social-cultural, and multicultural points of view.

Through case studies and discussions, you will see students experiencing success using student-centered curriculum approaches, thematic teaching, multi-age grouping, peer-mediated instruction, multicultural curriculum, authentic assessment, and much, much more!

The book includes "thought pieces" presenting main issues and questions brought about by new perspectives. Each thought piece is followed by practical ideas to improve classroom instruction. It also shows how to access perspectives from the students who are being taught. It allows teachers to know how their students learn best and how to plan curriculum for them. You will find a whole new approach to teaching in this new book.

\section{Special Features}

Links constructivism to special education practices

Includes proven classroom ideas

- Addresses diversity issues

Intended for both special and general classrooms

- Pragmatic, easy to use strategies

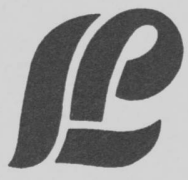




\section{Professional update}

\section{American Educational Research Association}

April 10-14, 2001

Seattle, WA

Contact: (202) 223-9485

http://www.aera.net

\section{Council for Exceptional Children}

April 18-21, 2001

Kansas City, MO

Contact: (800) 486-5773

http://www.cec.sped.org

\section{National Association of School Psychologists}

April 17-21, 2001

Washington, DC

Contact: (301) 657-0270

http://www.naspweb.org

\section{PERMISSIONS AND COPYRIGHT}

All rights are reserved. No part of this publication may be reproduced, photocopied, faxed, stored in a retrieval system, or transmitted in any form or by any means, electronic, mechanical, recording or otherwise, without the prior written permission of the publisher.
Back issues are available for sale. Reproduction requires permission and payment of fees. It is illegal and a violation of federal copyright law to reproduce this publication without permission. Direct all inquiries to the permissions editor. 